\title{
Meningkatkan Aktifitas Belajar Matematika Materi Pecahan Dengan Menggunakan Model Kooperatif Tipe Jigsaw Pada Siswa Kelas IV SDN NO. 101/II Muara Bungo Kec. Pasar Muara Bungo Kab. Bungo
}

\author{
Yusmaherni \\ Sekolah Dasar Negeri 101/II Muara Bungo \\ yusmaherni@yahoo.com
}

\begin{abstract}
Abstrak
Tujuan penelitian ini adalah meningkatkan keaktifan dan hasil belajar siswa pada pembelajaran pecahan dengan menggunakan model Jigsaw di Kelas IV di SDN No. 101/II Muara Bungo Kecamatan Pasar Muara Bungo Kabupaten Bungo. Subjek dalam penelitian ini adalah siswa kelas IV SDN No. 101/II Muara Bungo Kecamatan Pasar Muara Bungo. Prosedur penelitian tindakan dilakukan dengan memberikan pembelajaran dengan model pembelajaran kooperatif tipe Jigsaw, yang terdiri dari beberapa langkah dengan perencanaan sebagai berikut: Perencanaan, Pelaksanaan, Observasi/ Evaluasi, Analisis dan Refleksi. Setelah melakukan penelitian tindakan kelas yang menggunakan pola tiga siklus, maka penelitian ini dapat disimpulkan bahwa penggunaan model pembelajaran Kooperatif type Jigsaw dalam penelitian ini dapat meningkatkan keaktifan dan hasil belajar siswa pada materi pecahan yang efektif diterapkan. Hal ini terlihat dari rata-rata persentase keaktifan belajar siswa seluruh indikator yang semakin meningkat dari keaktifan belajar siswa siklus I rata-rata persentase skor aktivitas untuk seluruh siswa mencapai $64,81 \%$, siklus II meningkat menjadi $73,70 \%$, dan siklus III meningkat menjadi $83,70 \%$. Hasil belajar siswa meningkat siklus I terdapat 12 orang siswa yang tuntas belajar $(37,50 \%)$, siklus II terjadi peningkatan siswa yang tuntas belajar yaitu 23 orang $(71,78 \%)$, dan siklus III ketuntasan belajar meningkat secara signifikan yaitu 29 orang $(90,62 \%)$ tuntas belajar.
\end{abstract}

Kata Kunci: Meningkatkan Aktifitas Belajar Matematika, Materi Pecahan, Model Kooperatif, Tipe Jigsaw

\begin{abstract}
The purpose of this research is to improve students' activity and learning outcomes in fractional learning by using Jigsaw model in Class IV di SDN No. 101/II Muara Bungo Kecamatan Pasar Muara Bungo Kabupaten Bungo. Subjects in this study were class students IV SDN No. 101/II Muara Bungo Kecamatan Pasar Muara Bungo. The action research procedure is done by providing learning with Jigsaw type cooperative learning model, which consists of several steps with the planning as follows: Planning, Implementation, Observation / Evaluation, Analysis and Reflection. After conducting classroom action research using three cycle pattern, this research can be concluded that the use of cooperative learning model type Jigsaw in this research can improve students' activity and learning achievement on fractional material that is effectively applied. This is seen from the average percentage of students' learning activeness of all the increasing indicators of student learning activity cycle I average percentage of activity score for all students reached $64.81 \%$, cycle II increased to $73.70 \%$, and cycle III increased to $83.70 \%$. The result of student learning increased cycle I there are 12 students who complete the study $(37,50 \%)$, cycle II happened improvement of complete student study that is 23 people $(71,78 \%)$, and cycle III mastery learning increased significantly that is 29 person 90,62\%) complete study.
\end{abstract}

Keywords: Improving Mathematics Learning Activities, Fractional Materials, Jigsaw Type Cooperative Models 


\section{PENDAHULUAN}

Untuk meningkatkan prestasi belajar siswa maka guru dituntut untuk membuat pembelajaran menjadi lebih inovatif yang mendorong siswa dapat belajar secara optimal baik di dalam belajar mandiri maupun di dalam pembelajaran di kelas. Inovasi model-model pembelajaran diperlukan untuk menghasilkan model pembelajaran baru yang dapat memberikan hasil belajar lebih baik, peningkatan efisiensi dan efektivitas pembelajaran menuju pembaharuan. Agar pembelajaran lebih optimal maka media pembelajaran harus efektif dan selektif sesuai dengan pokok bahasan yang diajarkan di dalam meningkatkan prestasi belajar siswa.

Hasil analisis ulangan harian pada materi pecahan tahun pelajaran 2015/2016 di SDN No. 101/II Muara Bungo Kecamatan Pasar Muara Bungo Kabupaten Bungo kelas IV pada mata pelajaran Matematika secara klasikal hanya $48 \%$ siswa mencapai nilai 7,0 ke atas dan rata-rata nilai prestasi siswa hanya mencapai nilai 6,00. Dari hasil ulangan harian tersebut, hanya 12 orang dari 32 siswa kelas IV SDN No. 101/II Muara Bungo Kecamatan Pasar Muara Bungo Kabupaten Bungo yang mencapai tingkat penguasaan materi sebesar $78 \%$ ke atas pada mata pelajaran Matematika materi pecahan. Selama pembelajaran berlangsung, siswa pada umumnya bersifat pasif, jarang sekali siswa mengajukan pertanyaan atau memberi tanggapan terhadap penjelasan guru. Berdasarkan hal tersebut, penulis melakukan identifikasi permasalahan dalam pembelajaran antara lain: (1) Penguasaan anak terhadap materi pembelajaran pecahan rendah. (2) Tidak semua anak dapat menjawab pertanyaan yang diajukan guru dengan baik dan benar tentang pecahan. (3) Anak kurang mampu untuk melaksanakan tugas yang diberikan guru. (4) Anak kurang dilibatkan dalam proses pembelajaran karena metode yang terlalu terpaku pada guru. (5) Terdapat pemahaman yang kurang merata diantara semua siswa tentang materi pembelajaran pecahan.

Dalam upaya mengatasi serta meningkatkan mutu pendidikan Matematika yang selama ini sangat rendah, dapat dilakukan dengan beberapa cara antara lain meningkatkan pengguna model, metode, atau strategi serta kwalitas guru agar merniliki dasar yang mantap sehingga dapat mentransfer ilmu dalam 
mempersiapkan kualitas sumber daya manusia. Secara umum, pendidikan sebenarnya merupakan suatu faktor rangkaian kegiatan komunikasi antar manusia. Kegiatan tersebut dalam dunia pendidikan disebut dengan kegiatan proses belajar mengajar yang dipengaruhi oleh faktor yang menentukan keberhasilan siswa.

Model pembelajaran Jigsaw adalah salah satu model pembelajaran kooperatif yang terdiri dari tim-tim belajar heterogen beranggotakan 4 sampai 6 orang siswa, (Arends, 1997). Materi akademik disajikan dalam bentuk teks dan setiap siswa bertanggung jawab atas penugasan bagian materi belajar dan mampu mengajar bagian materi tersebut kepada anggota tim lain. Tujuan penelitian ini adalah meningkatkan Keaktifan Belajar Siswa pada Pembelajaran Pecahan dengan menggunakan Model Jigsaw di Kelas IV SDN No. 101/II Muara Bungo Kecamatan Pasar Muara Bungo Kabupaten Bungo".

\section{METODE PENELITIAN}

Penelitian ini menggunanakan metode penelitian tindakan kelas (PTK) degan prosedur sebagai berikut : Perencanaan, Pelaksanaan, Observasi/ Evaluasi, Analisis dan Refleksi. Data dalam penelitian ini dikumpulkan melalui catatan lapangan dan lembar observasi yang berupa catatan temuan-temuan atau tindakan yang peneliti lakukan selama berlangsung proses pembelajaran. Analisa data dilakukan terhadap hasil observasi yang dilakukan dalam proses belajar mengajar dengan menggunakan alat bantu yang telah disiapkan berupa catatan berdasarkan lembar observasi. Analisis terhadap data kualitatif yaitu dengan pengambilan data tentang keaktifan siswa dan guru dalam proses pembelajaran.

Penelitian tindakan kelas ini berhasil apabila terjadi peningkatan kualitas pelaksanaan pembelajaran pada materi pecahan yang menggunakan model pembelajaran kooperatif tipe Jigsaw jika mencapai nilai standar kriteria ketuntasan minimal (KKM) yaitu nilai 65 dengan persentase ketuntasan klasikal mencapai $85 \%$ dan aktifitas siswa dikatakan aktif jika mencapai nilai persentase mencapai $70 \%$. 


\section{HASIL DAN PEMBAHASAN}

Penelitian siklus I dilaksanakan pada tanggal 4 Februari 2015. Setiap pertemuan dilakukan selama dua jam pelajaran. Penelitian ini dibagi dalam 4 (empat) kegiatan yaitu: 1) perencanaan 2) pelaksanaan tindakan 3) observasi dan evaluasi dan 4) analisis dan refleksi.

Pada tahap perencanaan siklus I yang menggunakan model pembelajaran Jigsaw yaitu mempersiapkan perangkat pembelajaran yang akan dilakukan pada tahap pelaksanaan tindakan. Adapun persiapan yang dibuat adalah menganalisis, membuat Rencana Pelaksanaan Pembelajaran (RPP), menyediakan media pembelajaran, membuat lembar kerja siswa, membuat instrumen penelitian aktivitas siswa, membuat lembar observasi aktivitas siswa dan guru, membuat alat evaluasi pembelajaran.

Pelaksanaan tindakan yang dilakukan pada siklus I yaitu pada kegiatan Awal: 1) Apersepsi, guru mengajak siswa untuk mengingat pembelajaran Matematika yang telah dipelajari pada kelas IV tentang menentukan pecahan, 2) Guru menyampaikan tujuan pembelajaran yang akan dipelajari tentang mengubah pecahan biasa ke dalam bentuk persen serta sebaliknya, 3) Guru memberikan motivasi pada siswa dengan mengaitkan pembelajaran pecahan dengan kegiatan sehari-hari misalnya diskon.

Pada kegiatan inti yaitu 1) Eksplorasi, sebelum proses pembelajaran dimulai guru memberikan penjelasan tentang cara kerja kelompok yang harus ditempuh siswa secara bertahap. Guru mempersiapkan materi atau tugas yang harus dipelajari siswa secara berkelompok. Setelah dipersiapkan guru langsung memberikan materi dari tugas pada masing-masing kelompok. Guru membagi siswa dalam beberapa kelompok yang mana setiap kelompok terdiri dari 4 orang secara heterogen yaitu berdasarkan jenis kelamin, kecerdasan, suku dan agama. Dalam satu kelompok tugas masing-masing siswa berbeda dan semua kelompok tugasnya sama. 2) Elaborasi, siswa bekerja dalam kelompok masing-masing dan membahas materi yang berbeda yang diberikan oleh guru. Setelah menyelesaikan tugas dalam kelompok, utusan kelompok bertemu untuk menyesuaikan hasil diskusi dalam kelompoknya dengan kelompok lain. Siswa saling mengemukakan 
pendapatnya di dalam kelompok tim ahli. Utusan kelompok tim ahli kembali ke kelompok asalnya dan menyampaikan hasil dari beberapa kelompok lain kepada teman-temannya. 3) Konfirmasi, setelah selesai menyampaikan hasil dari tim ahli (utusan kelompok), utusan kelompok menyampaikan hasil diskusinya di depan kelas. Guru menanggapi pekerjaan atau hasil jawaban siswa dan memberi informasi yang sebenamya atau jawaban yang benar. Setelah selesai kegiatan kelompok, guru mengedarkan tes atau evaluasi. Evaluasi dilakukan secara individu dan tidak boleh saling membantu dan ternyata hasil kerja kelompoknya sangat kurang aktif.

Pada kegiatan akhir guru melakukan kegiatan umpan balik yakni kegiatan tanya jawab yang berkaitan dengan materi yang telah dipelajari. Kegiatan ini untuk melihat seberapa jauh pemahaman siswa terhadap materi yang telah diberikan, Pada tahap ini siswa masih banyak yang salah mengoreksi hasil pekerjaan teman sekelompok. Tahap selanjutnya guru memberikan kesimpulan atas materi yang telah dipelajari dan akhir kegiatan guru memberikan kegiatan tindak lanjut yaitu menyuruh siswa untuk mempelajari materi pertemuan yang akan datang tentang mengubah pecahan biasa ke bentuk desimal dan sebaliknya.

Berdasarkan pada siklus I ini masih banyak siswa dengan hasil belajar yang masih rendah. Dari 32 siswa, hanya 12 siswa $(37,50 \%)$ yang tergolong tuntas dengan persentase nilai di atas 65, sedangkan sisanya sebanyak 20 siswa $(62,50 \%)$ tidak tuntas dalam penguasaan materi pecahan. Hasil penelitian siklus I yang menggunakan model pembelajaran kooperatif tipe jigsaw terlihat bahwa masih banyak siswa yang belum aktif dalam belajar. Beberapa indikator yang perlu ditingkatkan atau diperbaiki yaitu tidak aktif mengoreksi hasil pekerjaan teman dalam satu kelompok, belum aktif menjawab bila ada pertanyaan dari guru atau dari teman, tidak aktif bertanya bila menemukan kesulitan, belum aktif mengerjakan tugas secara sendiri pada saat diskusi, tidak aktif berdiskusi dalam kelompok, dan belum dapat bekerjasama dalam kelompok.

Siklus II merupakan tindak lanjut yang telah dilakukan pada siklus I. Pada siklus II telah dipersiapkan dan direncanakan lebih baik karena pada siklus ini 
upaya peningkatan keaktifan siswa ke arah yang lebih baik dari siklus I. Pelaksanaan siklus II dilaksanakan pada tanggal 10 Februari 2015.

Pada tahap perencanaan siklus II yang menggunakan model pembelajaran Jigsaw yaitu mempersiapkan perangkat pembelajaran yang akan dilakukan pada tahap pelaksanaan tindakan. Adapun persiapan yang dibuat adalah: 1) membuat Rencana Pelaksanaan Pembelajaran (RPP), 2) menyediakan Media Pembelajaran (alat peraga dari karton), 3) membuat Lembar Kerja Siswa, 4) membuat Instrumen Penelitian Aktivitas Siswa, 5) membuat Lembar Observasi Aktivitas Siswa dan Guru, 6) membuat alat evaluasi pembelajaran.

Pelaksanaan tindakan yang dilakukan pada siklus II sama halnya yang dilakukan pada siklus I. Pada siklus II melaksanakan pembelajaran yang menggunakan model pembelajaran tipe Jigsaw dengan menggunakan alat peraga yang berupa karton dengan menekankan perbaikan dan peningkatan keaktifan belajar siswa yang telah dilakukan pada siklus I.

Adapun langkah tindakan yang dilakukan pada siklus II di kegiatan awal yaitu : 1) Apersepsi, guru mengajak siswa untuk mengingat pembelajaran Matematika yang telah dipelajari yaitu mengubah pecahan biasa ke bentuk persen dan sebaliknya. 2) Guru menyampaikan tujuan pembelajaran yang akan dipelajari tentang mengubah pecahan biasa ke bentuk desimal serta sebaliknya. 3) Guru memberikan motivasi pada siswa dengan menjelaskan materi secara garis besar menggunakan alat peraga di karton.

Pada kegiatan inti yang dilakukan guru adalah 1) Eksplorasi, sebelum proses pembelajaran dimulai guru memberikan penjelasan tentang cara kerja kelompok yang harus ditempuh siswa secara bertahap. Guru mempersiapkan materi atau tugas yang harus dipelajari siswa secara berkelompok. Setelah dipersiapkan guru langsung memberikan materi dan tugas pada masing-masing kelompok. Guru membagi siswa dalam beberapa kelompok yang mana setiap kelompok terdiri dari 4 orang secara heterogen yaitu berdasarkan jenis kelamin, kecerdasan, suku dan agama. Dalam satu kelompok tugas masing-masing siswa berbeda dan semua kelompok tugasnya sama. 2) Elaborasi, siswa bekerja dalam kelompok masing-masing dan membahas materi yang berbeda yang diberikan 
oleh guru. Setelah menyelesaikan tugas dalam kelompok, utusan kelompok bertemu untuk menyesuaikan hasil diskusi dalam kelompoknya dengan kelompok lain. Siswa saling mengemukakan pendapatnya di dalam kelompok tim ahli. Utusan kelompok tim ahli kembali ke kelompok asalnya dan menyampaikan hasil dari beberapa kelompok lain kepada teman-temannya. 3) Konfirmasi, setelah selesai menyampaikan hasil dari tim ahli (utusan kelompok), utusan kelompok menyampaikan hasil diskusinya di depan kelas.

Guru menanggapi pekerjaan atau hasil jawaban siswa dan memberi informasi yang sebenarnya atau jawaban yang benar. Setelah selesai kegiatan kelompok, guru mengadakan tes atau evaluasi. Evaluasi dilakukan secara individu dan tidak boleh saling membantu dan ternyata hasil kerja kelompoknya sangat kurang aktif. 4) Pemberian umpan balik, yaitu mengadakan tanya jawab tentang materi yang telah dipelajari yaitu mengubah pecahan biasa ke bentuk desimal serta sebaliknya. Hal ini untuk mengukur pemahaman siswa terhadap penguasaan materi. Guru dan siswa menyimpulkan pembelajaran. Guru memberikan tugas pekerjaan rumah dan guru mengakhiri pelajaran dengan mengucapkan salam dan menyampaikan materi yang akan datang tentang mengubah pecahan desimal ke bentuk persen dan sebaliknya.

Pada kegiatan akhir guru melakukan kegiatan umpan balik yakni kegiatan tanya jawab yang berkaitan dengan materi yang telah dipelajari. Kegiatan ini untuk melihat seberapa jauh pemahaman siswa terhadap materi yang telah diberikan, pada tahap ini siswa masih banyak yang malu menjawab pertanyaan. Tahap selanjutnya guru memberikan kesimpulan atas materi yang telah dipelajari dan akhir kegiatan guru memberikan kegiatan tindak lanjut yaitu menyuruh siswa untuk mempelajari materi pertemuan yang akan dating yaitu tentang mengubah desimal ke bentuk persen dan sebaliknya.

Sepertihalnya siklus I, pada siklus II juga dilakukan obervasi kegiatan guru dalam pembelajaran dan aktivitas belajar siswa. Aktifitas guru mencapai skor $94,44 \%$ dikategorikan sangat baik. Dilihat dari semua indikator, 7 indikator tergolong sangat baik dan sisanya sebanyak 2 indikator tergolong baik. Hal ini berarti guru mampu melaksanakan pembelajaran dengan baik dengan model Tipe 
Jigsaw dalam pembelajaran materi pecahan. Beberapa indikator yang perlu ditingkatkan yaitu pada pemberian kegiatan umpan balik dan evaluasi secara individual. Kegiatan pembelajaran yang dilaksanakan oleh guru tentunya akan mempengaruhi aktivitas belajar siswa. Pembelajaran yang menarik akan mampu memancing siswa untuk terlibat aktif dalam pembelajaran. Hasil pengamatan aktivitas siswa dalam kegiatan pembelajaran pada siklus II sudah mengalami peningkatan dibandingkan dengan siklus sebelumnya.

Keaktifan siswa dalam kegiatan pembelajaran pada siklus II ini tergolong cukup baik dengan persentase rata-rata sebesar 72,92\%. Ada 8 siswa dengan tingkat keaktifan yang masih kurang baik, yang tentunya pembelajaran yang dilaksanakan selanjutnya harus mampu memancing aktivitas siswa supaya lebih aktif dalam mengikuti kegiatan pembelajaran yang dilaksanakan. Keaktifan tersebut tentunya berpengaruh terhadap hasil belajar siswa. Pada siklus II ini nilai rata-rata meningkat menjadi sebesar 7,65 dengan persentase nilai rata-rata sebesar 76,56. Dari 32 siswa, pada siklus II, sebanyak 23 siswa tergolong tuntas, dan sisanya sebanyak 9 siswa tergolong belum tuntas.

Hasil penelitian siklus II yang menggunakan model pembelajaran kooperatif tipe Jigsaw terlihat bahwa masih banyak siswa yang belum aktif dalam belajar. Beberapa indikator yang perlu ditingkatkan atau diperbaiki yaitu tidak aktif mengoreksi hasil pekerjaan teman dalam satu kelompok, belum aktif menjawab bila ada pertanyaan dari guru atau dari teman, tidak aktif bertanya bila menemukan kesulitan, belum aktif mengerjakan tugas secara sendiri pada saat diskusi, tidak aktif berdiskusi dalam kelompok, dan belum dapat bekerjasama dalam kelompok.

Siklus III merupakan tindak lanjut yang telah dilakukan pada siklus II. Pada siklus III telah dipersiapkan dan direncanakan lebih baik karena pada siklus ini upaya peningkatan keaktifan siswa ke arah yang lebih baik dari siklus II. Pelaksanaan siklus III dilaksanakan pada tanggal 16 Februari 2015.

Tahap ini merupakan tahap perencanaan tindakan yang akan dilakukan pada pelaksanaan tindakan yang menggunakan model pembelajaran kooperatif tipe Jigsaw. Adapun perangkat pembelajaran yang perlu dipersiapkan adalah 1) 
membuat Rencana Pelaksanaan Pembelajaran (RPP), 2) menyediakan Media Pembelajaran (alat peraga dari karton), 3) membuat Lembar Kerja Siswa, 4) membuat Instrumen Penelitian Aktivitas Siswa, 5) membuat Lembar Observasi Aktivitas Siswa dan Guru, 6) membuat alat evaluasi pembelajaran.

Pelaksanaan tindakan yang dilakukan pada siklus III sama halnya yang dilakukan pada siklus sebelumnya. Pada siklus III melaksanakan pembelajaran yang menggunakan model pembelajaran tipe Jigsaw dengan menggunakan alat peraga yang berupa karton dengan menekankan perbaikan dan peningkatan keaktifan belajar siswa yang telah dilakukan pada siklus II.

Adapun langkah tindakan yang dilakukan adalah pelaksanaan tindakan yang dilakukan pada siklus III yaitu 1) Kegiatan Awal. Apersepsi, guru mengajak siswa untuk mengingat pembelajaran Matematika yang telah dipelajari yaitu mengubah pecahan biasa ke bentuk desimal dan sebaliknya. Guru menyampaikan tujuan pembelajaran yang akan dipelajari tentang mengubah desimal ke bentuk persen serta sebaliknya. Guru memberikan motivasi pada siswa dengan menjelaskan materi secara garis besar menggunakan alat peraga di karton.

Pada Kegiatan Inti guru melakuakan : 1) Eksplorasi, sebelum proses pembelajaran dimulai guru memberikan penjelasantentang cara kerja kelompok yang harus ditempuh siswa secara bertahap. Guru mempersiapkan materi atau tugas yang harus dipelajari siswa secara berkelompok. Setelah dipersiapkan guru langsung memberikan materi dan tugas pada masing-masing kelompok. Guru membagi siswa dalam beberapa kelompok yang mana setiap kelompok terdiri dari 4 orang secara heterogen yaitu berdasarkan jenis kelamin, kecerdasan, suku dan agama. Dalam satu kelompok tugas masing-masing siswa berbeda dan semua kelompok tugasnya sama. 2) Elaborasi, siswa bekerja dalam kelompok masingmasing dan membahas materi yang berbeda yang diberikan oleh guru. Setelah menyelesaikan tugas dalam kelompok, utusan kelompok bertemu untuk menyesuaikan hasil diskusi dalam kelompoknya dengan kelompok lain.

Siswa saling mengemukakan pendapatnya di dalam kelompok tim ahli. Utusan kelompok tim ahli kembali ke kelompok asalnya dan menyampaikan hasil dari beberapa kelompok lain kepada teman-temannya. 3) Konfirmasi, setelah 
selesai menyampaikan hasil dari tim ahli (utusan kelompok), utusan kelompok menyampaikan hasil diskusinya di depan kelas. Guru menanggapi pekerjaan atau hasil jawaban siswa dan memberi informasi yang sebenarnya atau jawaban yang benar. Setelah selesai kegiatan kelompok, guru mengadakan tes atau evaluasi. Evaluasi dilakukan secara individu dan tidak boleh saling membantu dan ternyata hasil kerja kelompoknya sangat kurang aktif.

Kegiatan Akhir, pemberian umpan balik, yaitu mengadakan tanya jawab tentang materi yang telah dipelajari yaitu mengubah desimal ke bentuk persen serta sebaliknya. Hal ini untuk mengukur pemahaman siswa terhadap penguasaan materi. Guru dan siswa menyimpulkan pembelajaran serta mengadakan evaluasi dan tindak lanjut. Pada kegiatan akhir guru melakukan kegiatan umpan balik yakni kegiatan tanya jawab yang berkaitan dengan materi yang telah dipelajari. Tahap selanjutnya guru memberikan kesimpulan atas materi yang telah dipelajari dan akhir kegiatan guru memberikan kegiatan tindak lanjut yaitu menyuruh siswa untuk mempelajari materi pertemuan yang akan datang di rumah.

Pada saat pembelajaran dilakukan observasi terhadap aktivitas guru dan siswa. Dari 9 indikator penilaian aktivitas guru dalam kegiatan pembelajaran, hanya 1 yang tergolong baik, sedangkan sisanya tergolong sangat baik. Aktivitas siswa per individu meningkat dari siklus sebelumnya. Pada siklus III ini hanya 3 siswa yang masih tergolong cukup aktif dilihat dari aktivitas belajarnya. Sebanyak 13 siswa tergolong aktif, dan 16 lainnya tergolong sangat aktif. Pada siklus III terbukti bahwa penggunaan model Kooperatif tipe jigsaw dapat meningkatkan keaktifan siswa dalam belajar.

Tingkat keaktifan belajar siswa yang mengalami peningkatan dibandingkan pada siklus sebelumnya tentunya juga akan meningkatkan hasil belajarnya. Peningkatan hasil belajar siklus III dinyatakan tuntas mencapai 90,62\% dengan nilai rata-rata siswa 9,06. Hasil siklus III menunjukkan bahwa hanya 3 siswa dengan hasil belajar dengan kategori belum tuntas dengan nilai di bawah $68 \%$. Namun secara klasikal, hasil ini sudah terpenuhi dengan tercapainya $90,62 \%$ siswa dengan hasil belajar di atas 6,8 . 
Ketuntasan hasil belajar siswa meningkat mencapai minimal 85\%. . Adapun refleksi yang dilakukan dari tindakan siklus III yaitu 1) Guru dalam mengadakan apersepsi, motivasi dan menyampaikan tujuan pembelajaran yang diharapkan dilaksanakan dengan baik. Hal ini perlu dipertahankan oleh guru. 2) Pemberian LKS menggunakan soal-soal yang telah dipelajari sesuai dengan materi. 3) Pembagian kelompok siswa harus di pertahankan karena sesuai dengan kriteria yang heterogen.

Berdasarkan hasil penelitian yang dilakukan sebanyak 3 siklus terlihat adanya peningkatan keaktifan siswa dan hasil belajar siswa pada pembelajaran Matematika materi pecahan yang menggunakan model pembelajaran kooperatif tipe Jigsaw di SDN No. 101/II Muara Bungo Kecamatan Pasar Muara Bungo Kabupaten Bungo. mencapai 75\%, Siklus II terjadi peningkatan menjadi 94,44\%, dan siklus III meningkat menjadi 97,22\%. Sementara itu, pada keaktifan belajar siswa siklus I rata-rata persentase skor aktivitas untuk seluruh siswa mencapai $61,98 \%$, siklus II meningkat menjadi 72,92\%, dan siklus III meningkat menjadi 90,10\%. Dengan meningkatnya hasil observasi siswa berpengaruh terhadap peningkatan hasil belajar siswa.

Hasil belajar siswa meningkat tiap-tiap siklusnya. Pada siklus I terdapat 12 orang siswa yang tuntas belajar $(37,50 \%)$, siklus II terjadi peningkatan siswa yang tuntas belajar yaitu 23 orang $(71,78 \%)$, dan siklus III ketuntasan belajar meningkat secara signifikan yaitu 29 orang $(90,62 \%)$ tuntas belajar. Ini membuktikan bahwa penggunaan model pembelajaran kooperatif tipe Jigsaw dapat meningkatkan hasil belajar dan keaktifan belajar siswa SDN No. 101/II Muara Bungo Kecamatan Pasar Muara Bungo Kabupaten Bungo.

\section{KESIMPULAN DAN SARAN}

Penggunaan model pembelajaran Kooperatif type Jigsaw dalam penelitian ini dapat meningkatkan keaktifan dan hasil belajar siswa pada materi pecahan yang efektif diterapkan. Hal ini terlihat dari rata-rata persentase keaktifan belajar siswa seluruh indikator yang semakin meningkat dari keaktifan belajar siswa siklus I rata-rata persentase skor aktivitas untuk seluruh siswa mencapai 64,81\%, 
siklus II meningkat menjadi 73,70\%, dan siklus III meningkat menjadi 83,70\%. Hasil belajar siswa meningkat siklus I terdapat 12 orang siswa yang tuntas belajar (37,50\%), siklus II terjadi peningkatan siswa yang tuntas belajar yaitu 23 orang $(71,78 \%)$, dan siklus III ketuntasan belajar meningkat secara signifikan yaitu 29 orang $(90,62 \%)$ tuntas belajar.

Berdasarkan kesimpulan diatas tentang hasil yang ditentukan dalam PTK ini, maka penulis memberikan saran sebagai berikut 1) perlu menumbuhkan rasa percaya diri selama proses pembelajaran baik secara individu maupun kelompok dalam model pembelajaran kooperatif tipe Jigsaw, 2) sebelum mengajar guru harus mempersiapkan materi, di dalam LKS untuk dipelajari siswa secara mandiri tanpa bantuan guru, 3) guru harus sesering mungkin memotivasi siswa baik dalam individu maupun kelompok, karena tindakan ini mempengaruhi siswa untuk lebih semangat dalam kerja kelompok maupun kerja sendiri.

\section{DAFTAR PUSTAKA}

Arends, 1997, Model-model Pembelajaran Inovaif, (Online). Diakes 5 April 2012. Dimyati dan Mujiyono, 1999. Belajar dan Pembelajaran. Jakarta: Rineka Cipta. Djamarah, 2001. Strategi Belajar Mengajar, Jakarta: Rineka Cipta.

Elliot, 1978. Educational Psychology Effective Teaching, Effective Learning. Singapura: Mc Graw Hill Book.

Ekawarna, 2009. Penelitian Tindakan Kelas. FKIP UNJA.

Faturohman dan Sutikno. 2009. Strategi Belajar Mengajar. Bandung: Refika Aditama.

Gagne dan Briggs, 1979. Model Belajar. Jakarta: Bumi Aksara.

Hamalik, 2003. Proses Belajar Mengajar. Jakarta: Bumi Aksara.

Knirk dan Gustafon, 1986. Instructional Technology. A Systematic Approach to Education. New York: Rinehart and Winston.

Lie. A 1994. Cooperative Learning. Jakarta: PT. Gramedia Widiasarana Indonesia.

Makmun, 2003. Prinsip Pembelajaran. Jakarta: Bumi Aksara.

Paul D Dierich, 2001. Aktif Belajar. Jakarta: Rineka Cipta.

Sagala, 2003. Konsep dan Makna Pembelajaran. Bandung: Alfabeta.

SlaVn, dalam Lies Aryati, 2012. Meningkatkan Keaktifan dan Hasil Belajar Siswa Model TAI.

Sumiati dan Asrori, 2008. Strategi Pembelajaran. Bandung: Refika Aditama.

Winkel, dalam Lies Aryati, 2012. Meningkatkan Keaktifan dan Hasil Belajar Siswa Model TAI.

Yamin dan Ansari, 2009. Taktik Mengembangkan Kemampuan Individual Siswa. 